ks. Wojciech Życiński

Uniwersytet Papieski Jana Pawła II w Krakowie

\title{
Matki Izraela typem Matki Kościoła
}

Drugi Sobór Watykański w Konstytucji dogmatycznej o Kościele przypomina słowa św. Ambrożego stwierdzające, że Maryja stanowi pierwowzór (typus) Kościoła. Papież Paweł VI nazwał Ją Matką Kościoła. Izrael - poprzednik nowego Ludu Bożego - czcił nie tylko swoich wielkich patriarchów, ojców Narodu Wybranego, ale też z wielkim szacunkiem odnosił się do Matek Izraela. Matki te odegrały istotną rolę w historii tego narodu zarówno poprzez jego formację religijną w momentach niewierności Przymierzu, jak też udział w wyzwoleniu z nieszczęść niewoli i najazdów krajów ościennych. Ich historia i historia Narodu Wybranego staje się historią zbawienia i teologią Ludu Bożego. Poprzez miejsce i rolę tych Matek w wyzwoleniu, na ogół politycznym, Izraela egzegeza katolicka, idąc za tradycją patrystyczną, określa miejsce i rolę Maryi w dziele odkupienia człowieka dokonanego przez Chrystusa.

Wbrew przekonaniu Hansa Künga wyrażonego w stwierdzeniu, że Maryja w pierwszych świadectwach chrześcijańskich nie odgrywa w ogóle żadnej roli, a tytuł Theotokos zawdzięcza manipulacjom Cyryla z Aleksandrii i soboru odbywanego w Efezie, mieście „Wielkiej Matki” - Artemidy, Diany ${ }^{1}$, już w Starym Testamencie znajdujemy zapowiedzi i odniesienia dotyczące przyszłej Matki Mesjasza. Matki te, niejednokrotnie mimo słabości, a nawet grzechu, odegrały szczególną rolę w historii narodu i historii zbawczej. Bibliści podają różną ich liczbę. Na ogół waha się ona od czterech do kilkunastu. W perspektywie realizacji tejże historii stanowią one typ Matki Chrystusa, obiecanego Mesjasza.

\section{Sara}

Jej pierwotne imię było Saraj, czyli księżniczka. Abraham, jej mąż, zmienił je na Sara, bo tak polecił mu Bóg (por. Rdz 15, 16-17). Mimo bezpłodności,

${ }^{1}$ Por. H. Küng, Christ sein, München 1974, s. 448, 450, 452. 
w wieku dziewięćdziesięciu lat została matką Izaaka, który był pierwszym synem Sary i Abrahama. Według Księgi Rodzaju narodziny Izaaka dokonały się wskutek interwencji Boga. Wcześniej Bóg zawarł z Abrahamem przymierze, w którym otrzymał on Bożą obietnicę zostania ojcem mnóstwa narodów i niedającego się zliczyć potomstwa (por. Rdz 17, 1-21). Ponieważ nie miał męskiego potomka, pierworodnego syna Izmaela urodziła mu jego niewolnica Hagar (por. Rdz 16, 1-2). W ten sposób Abraham zamierzał zapewnić sobie potomstwo, o którym mówił mu Bóg. Bezpłodność Sary i zaawansowany - zarówno jej, jak i Abrahama - wiek stają się znakami bezpośredniej interwencji Boga, który swój zbawczy plan realizuje niezależnie od przekonań i naturalnych uwarunkowań ludzkich. Dlatego za pośrednictwem anioła informuje Abrahama o poczęciu przez Sarę Izaaka, który będzie spadkobiercą obietnicy, którą mu wcześniej złożył².

Narodziny Jezusa z Maryi również dokonały się dzięki działaniu Ducha Świętego (por. Łk 1,35).W tym przypadku również pośredniczy anioł, który oznajmia przyszłej Matce Pana Bożą wolę dotyczącą wybrania i przeznaczenia Jej do macierzyństwa Bożego Syna. Tak jak Sara jest zapowiedzią Przymierza zawartego przez Boga z Abrahamem i potwierdzonego krwią obrzezania, tak Maryja zapowiada, a nawet już zapoczątkowuje Nowe Przymierze Boga z ludzkością, potwierdzone krzyżową ofiarą i krwią Chrystusa ${ }^{3}$.

\section{Anna}

Była żoną Elkany, syna Jerochama z Ramataim. Podobnie jak Sara była bezpłodna, co było powodem pogardy często okazywanej jej przez Peninnę, drugą żonę Elkany. Podczas pielgrzymki do sanktuarium w Szilo, gdzie służbę kapłańską pełnił Heli, złożyła Bogu obietnicę: „Panie Zastępów! Jeżeli łaskawie wejrzysz na poniżenie służebnicy twojej i wspomnisz na mnie, i nie zapomnisz służebnicy twojej, i dasz mi potomka płci męskiej, wtedy oddam go Panu po wszystkie dni jego życia, a brzytwa nie dotknie jego głowy" (1 Sm 1, 11). Bóg wysłuchał jej prośby, porodziła syna, któremu nadano imię Samuel, co oznacza „Bóg wysłuchał” (1 Sm 1, 20). Kiedy Samuel dorósł, Anna wypełniła obietnicę, oddając go na służbę w świątyni pod opiekę Helego, wypowiadając przy tym modlitwę dziękczynną, która przez teologów uważana jest za mesjański kantyk o nadziei, jaką pokładają w Bogu ludzie biedni i pogardzani (por. $1 \mathrm{Sm} \mathrm{2,1-10).}$

Zarówno syn bezpłodnej Sary - Izaak, jak i syn Anny - Samuel są ludźmi powołanymi przez Boga do szczególnej funkcji w realizacji zbawczego planu.

\footnotetext{
${ }^{2}$ Por. C. I. González, Mariologia. Maria, madre e discepola, Bogotà 1988, s. 33.

${ }^{3}$ Por. Th. Kaylaparambil, Figures and Symbols of Mary In the Old Testament, „Biblehas” 3 (1977), $247-248$.
} 
Izaak to pierwszy po Abrahamie patriarcha Izraela. Samuel został wielkim prorokiem bezkompromisowo głoszącym słowo Boże. Bóg interweniując w obu tych przypadkach, nie czynił tego, by zaspokoić pragnienia upokorzonych niewiast, ale kierował się dobrem Narodu Izraela ${ }^{4}$.

Teologia biblijna postrzega w Annie typ Matki Jezusa. Anna, prosząc Boga o syna, określa się mianem służebnicy Pana. Maryja, odpowiadając na słowa anioła, kiedy ten poinformował Ją, że pocznie i porodzi Syna, który będzie Synem Najwyższego, również określa siebie mianem Służebnicy Pańskiej. Anna po ofiarowaniu Samuela w świątyni wypowiada hymn dziękczynny na cześć Boga. Maryja w domu Zachariasza i Elżbiety również wypowiada hymn ku czci Boga. Uderzające jest podobieństwo obu tych tekstów ${ }^{5}$, które sprawia wrażenie, jakby Maryja posiłkowała się dziękczynną modlitwą matki proroka Samuela. Analiza treściowa modlitwy Anny wskazuje już na późniejszy program działalności prorockiej jej syna, skoncentrowanej na trosce o wierność słowu Boga. Podobnie Magnificat Maryi zapowiada istotną treść Ewangelii Łukaszowej, ukazującej Syna Bożego zrodzonego z Maryi, który poniża dumnych, możnych i bogatych, a wywyższa głodnych i pokornych. Przyszedł bowiem do chorych, słabych, grzesznych i ubogich.

Obie matki jednoczy ponadto sytuacja ubóstwa. W istocie chodzi nie tylko o ubóstwo materialne, choć w przypadku Anny takim ubóstwem była niewątpliwie jej bezpłodność. Chodzi raczej o biblijną ideę, rozwijaną zwłaszcza po powrocie z niewoli babilońskiej, przynależności do ubogich Jahwe (anawim), czyli o religijną postawę Izraelity, który jedynie w Bogu pokłada swoją nadzieję i wiernie zachowuje

${ }^{4}$ Por. C. I. González, Mariologia, dz. cyt., s. 33-34.

${ }^{5}$ Hymn Anny: „Raduje się me serce w Panu, moc moja wzrasta dzięki Panu, rozwarły się me usta na wrogów moich, gdyż cieszyć się mogę Twoją pomocą. Nikt tak święty jak Pan, prócz Ciebie nie ma nikogo, nikt taką Skałą jak Bóg nasz. Nie mówcie więcej słów pełnych pychy, z ust waszych niech nie wychodzą słowa wyniosłe, bo Pan jest Bogiem wszechwiedzącym: On waży uczynki. Łuk mocarzy się łamie, a słabi przepasują się mocą, za chleb najmują się syci, a głodni [już] odpoczywają, niepłodna rodzi siedmioro, a wielodzietna więdnie. To Pan daje śmierć i życie, wtrąca do Szeolu i zeń wyprowadza. Pan uboży i wzbogaca, poniża i wywyższa. Z pyłu podnosi biedaka, z barłogu dźwiga nędzarza, by go wśród możnych posadzić, by dać mu tron zaszczytny. Do Pana należą filary ziemi: na nich świat położył. On ochrania stopy pobożnych. Występni zginą w ciemnościach, bo nie [swoją] siłą człowiek zwycięża. Pan wniwecz obraca opornych: przeciw nim grzmi na niebiosach. Pan osądza krańce ziemi, On daje potęgę królowi, wywyższa moc swego pomazańca” (1 Sm 1, 1-10).

Hymn Maryi: „Wielbi dusza moja Pana i raduje się duch mój w Bogu, moim Zbawcy. Bo wejrzał na uniżenie Służebnicy swojej. Oto bowiem błogosławić mnie będą odtąd wszystkie pokolenia, gdyż wielkie rzeczy uczynił mi Wszechmocny. Święte jest Jego imię - a swoje miłosierdzie na pokolenia i pokolenia [zachowuje] dla tych, co się Go boją. On przejawia moc ramienia swego, rozprasza [ludzi] pyszniących się zamysłami serc swoich. Strąca władców z tronu, a wywyższa pokornych. Głodnych nasyca dobrami, a bogatych z niczym odprawia. Ujął się za swoim sługą, Izraelem, pomny na miłosierdzie swoje - jak przyobiecał naszym ojcom - na rzecz Abrahama i jego potomstwa na wieki” (Łk 1, 46-55). 
prawo Przymierza ${ }^{6}$. Tak Anna, jak Maryja kryteria te spełniały. W przypadku pierwszej postrzegać należy starotestamentalną kategorię ubogich Jahwe, a w przypadku drugiej nowotestamentalną kategorię ubogich w duchu.

\section{Rebeka}

Żona, a zarazem kuzynka Izaaka, syna Abrahama. Była córką Betuela, syna Milki, żony Nachora, który był bratem Abrahama, i siostrą Labana (por. Rdz 24, 29-30). Patriarcha nie chciał bowiem, aby jego syn poślubił niewiastę kananejską. Posłał więc swego sługę do kraju przodków, by tam znalazł żonę dla syna. Po dwudziestu latach bezpłodności, jako żona Izaaka, urodziła bliźnięta: Ezawa i Jakuba. Wyraźnie faworyzowała tego drugiego, o czym świadczyć może opis podstępnego uzyskania błogosławieństwa dla Jakuba, jakiego udzielił mu umierający Izaak, mimo że przysługiwało ono Ezawowi (por. Rdz 27, 1-29) 7 .

Wysłanie przez Abrahama posłańca do domu swego ojca celem znalezienia tam żony dla swojego syna uważane jest za symbol działania Boga posyłającego Gabriela do Maryi, by powiedzieć Jej, że zostanie matką Emmanuela ${ }^{8}$. Rebeka, zgadzając się zostać żoną Izaaka i matką Jakuba, symbolizuje postawę Maryi ukazaną w Łukaszowym opisie zwiastowania. Wobec Niej też zrealizowane zostały słowa błogosławieństwa, jakiego przed wyjazdem do domu Izaaka udzielili Rebece jej bracia: „Siostro nasza, wzrastaj w tysiące nieprzeliczone: i niech potomstwo twoje zdobędzie bramy swych nieprzyjaciół” (Rdz 24, 60).

To właśnie Rebeka, używając podstępu, wymusiła na mężu swym Izaaku udzielenie błogosławieństwa Jakubowi, mimo iż należało się ono Ezawowi. Kiedy niewidomy już i umierający Izaak wyraził wobec pierworodnego Ezawa swoją ostatnią wolę, którą słyszała Rebeka, zdecydowała, by dziedzictwo rodu i ojcowskie błogosławieństwo otrzymał nie Ezaw, ale Jakub. Ubrała go w szaty brata, na jego nieowłosione ręce i szyję przykleiła skórę koźląt, a następnie, po przygotowaniu ulubionej potrawy Izaaka, wysłała Jakuba do ojca. Błogosławieństwo otrzymał Jakub, jego potomstwo i lud (por. Rdz 27, 5-17; 28, 1-5). Teologia patrystyczna, a także współczesna wydarzenie to interpretuje w kontekście mariologicznym. Postawa Rebeki bowiem symbolizuje postawę Maryi ukazaną podczas zwiastowania. Maryja decydując się na zostanie Matką Syna Bożego, umożliwiła też Synowi Najwyższego, by przyjął ludzkie ciało i stałnie się błogosławieństwem dla Ludu

\footnotetext{
${ }^{6}$ Por. A. Serra, La donna dell'Alleanza. Prefigurazioni di Maria nell'Antico Testamento, Padova 2006, s. 59

${ }^{7}$ Św. Paweł uważa wyróżnienie Jakuba przez Rebekę za symbol wolności Bożego wyboru (por. Rz 9, 10-13).

${ }^{8}$ Por. S. M. Manelli, Mariologia Biblica, Frigento 2005, s. 65.
} 
Bożego9. Jak Rebeka pośredniczyła w otrzymaniu Izaakowego błogosławieństwa przez Jakuba, tak Maryja pośredniczyła w otrzymaniu Bożego błogosławieństwa przez lud Nowego Izraela oczekujący odkupienia, które to odkupienie zrealizowane zostało przez Jej Syna Jezusa.

\section{Rachela}

Młodsza i, jak mówi Biblia, piękniejsza córka Labana, brata Rebeki, siostra Lei i druga żona Jakuba, syna Izaaka. Jakub za siedmioletnią służbę u Labana miał ją otrzymać za żonę. Został jednak oszukany przez Labana i dopiero po następnych siedmiu latach służby Rachela została jego żoną. Była matką jego synów: Józefa i Beniamina, przy którego porodzie zmarła. Józef, według świadectwa Biblii, sprzedany został kupcom egipskim. Ten czyn braci Józefa, dokonany z premedytacją, w przyszłości okazał się zbawienny tak dla samego rodu Jakuba, jak i dla całego ludu izraelskiego. Biblia Nowego Testamentu postrzega w Racheli nie tylko symboliczną „figurę" matek, które opłakiwały swych synów po rzezi niemowląt dokonanej przez Heroda w Betlejem i okolicy, ale także typ Matki Jezusa. Izraelici nazywają Rachelę ,naszą matką”.

Patriarcha Jakub wobec zbliżającej się już śmierci przywołał swoich synów i wobec każdego z nich wypowiedział słowa błogosławieństwa. Do Józefa, syna Racheli, powiedział:

Od Boga ojców twoich, który cię będzie wspomagał, od Wszechmocnego, który ci będzie błogosławił - błogosławieństwa z niebios wysokich, błogosławieństwa otchłani leżącej najniżej, błogosławieństwa piersi i łona. Błogosławieństwa ojca twego niech dłużej trwają niż błogosławieństwa mych przodków, jak długo trwać będą pagórki odwieczne - niechaj spłyną na głowę Józefa, na głowę tego, który jest księciem wśród swoich braci (Rdz 49, 25-26).

O błogosławieństwie piersi i łona matki wspomina zarówno palestyński Targum, jak i Ewangelia Łukasza słowami niewiasty z tłumu (por. Łk 11, 27). Nie można wykluczyć, że owa niewiasta, wypowiadając słowa uznania kierowane do Matki Jezusa, cytowała modlitwę Targumu i patriarchy Jakuba ${ }^{10}$. Tradycja Kościoła postrzega Józefa jako symbol Jezusa. Józef - sprzedany przez braci Egipcjanom - okazał się ratunkiem dla Izraela w najtrudniejszych czasach. Jezus - wydany przez Judasza przywódcom Izraela - okazał się Odkupicielem rodzaju ludzkiego ${ }^{11}$. Rachela natomiast symbolizuje Maryję. Radość towarzyszyła Racheli podczas narodzin Józefa.

\footnotetext{
${ }^{9}$ Por. tamże, s. 65.

${ }^{10}$ Por. A. Serra, La Donna dell'Alleanza, dz. cyt., s. 28.

${ }^{11}$ Por. tamże, s. 66-67.
} 
Rachela zmarła bezpośrednio po urodzeniu Beniamina. Wcześniej zdążyła nazwać go imieniem Benoni, co oznacza „syn bólu”. Ojciec jednak dał mu imię Beniamin, czyli „syn prawicy”, „syn szczęścia”. Radość towarzyszyła Maryi podczas narodzin Jezusa, ból natomiast pod krzyżem, gdzie umierający Chrystus dopełniał dzieła odkupienia ludzkości i gdzie rodził się Kościół ${ }^{12}$.

Paralelę między Rachelą a Maryją dostrzega też współczesna teologia żydowska. Robi to m.in. Edmund Fleg, współzałożyciel Towarzystwa Przyjaźni Żydowsko-Chrześcijańskiej. Macierzyńskiego bólu, jak twierdzi, doświadczyła zarówno Rachela, jak i Maryja. Matka Jezusa cierpiała przede wszystkim pod krzyżem. Cierpiała również Rachela i wszystkie inne matki, niezależnie od tego, czy były to Żydówki, czy nie, kiedy musiały patrzeć na śmierć swoich dzieci. Pisze E. Fleg:

Spoliczkowano twego syna, dziewico Maryjo, ukoronowano go cierniem, wywyższono na krzyżu. Płaczesz, dziewico Maryjo, płaczesz u stóp krzyża, ale z tobą płaczą także inni. Czy nie dostrzegasz tego, że lamentuje również inna matka? Czy w swoim bólu nie dostrzegasz innej matki, daleko bardziej cierpiącej od ciebie? Nie dostrzegasz naszej matki Racheli, która opłakuje swoje dzieci? Swoich maleńkich pierworodnych, których nosi w łonie. Jednego po drugim, tysiące po tysiącach. Okrutny faraon wrzuca ich do Nilu. Tak płacze Rachela, tak się płaczem zanosi. Popatrz, dziewico Maryjo, która opłakujesz swojego jedynego syna, popatrz na naszą matkę Rachelę, która opłakuje miliony swoich synów ${ }^{13}$.

Na koniec pyta, czy Jezusowa obietnica powstania z martwych była dla Maryi pocieszeniem? Tak bowiem twierdził urodzony w Wiedniu, a zmarły w 2000 roku inny przedstawiciel teologii żydowskiej, jakim był Dawid Flusser. W 1985 roku zasłynął nie tylko w Izraelu, ale i poza nim, zakładając z Robertem Lindleyem Jerozolimską Szkołę Studiów nad Ewangeliami Synoptycznymi. Maryja, według D. Flussera, cierpiała nie tylko pod krzyżem, ale również podczas publicznej działalności Jezusa, ponieważ zupełnie nie rozumiała decyzji swojego Syna. Racheli natomiast ten rodzaj cierpienia został oszczędzony ${ }^{14}$.

\section{Miriam}

Według tradycji kapłańskiej była siostrą Mojżesza, wyzwoliciela narodu izraelskiego z niewoli egipskiej i prawodawcy, oraz Aarona, pierwszego kapłana Starego Przymierza, których matką była Jokebed. Wydatnie przyczyniła się do uratowania życia Mojżesza, łamiąc nakaz faraona, dotyczący zabijania nowo narodzonych chłopców

\footnotetext{
${ }^{12}$ Por. E. Zolli, Da Eva a Maria, Frigento 2004, s. 80-83.

${ }^{13}$ E. Fleg, L'Enfant prophète, Paris 1926, s. 144 (przekład W. Ż.).

${ }^{14}$ Por. D. Flusser, Jesus, Brescia 1997, s. 47.
} 
izraelskich (por. Wj 1, 22). Podczas wędrówki Izraelitów do Ziemi Obiecanej nie była już tak życzliwa wobec brata, zarzucając mu przede wszystkim złe traktowanie ludu i poślubienie Kuszytki. Została nawet ukarana trądem, z którego uleczył ją Bóg na prośbę Mojżesza. Biblia nazywa ją też prorokinią (por. Wj 15, 20).

Ten ostatni aspekt podejmuje w swoich rozważaniach Eugenio Zolli, najpierw rabin, a następnie rzymski katolik. Komentując tekst Micheasza: „Otom cię wywiódł z ziemi egipskiej, z domu niewoli wybawiłem ciebie i posłałem przed obliczem twoim Mojżesza, Aarona i Miriam" (Mi 6, 4), zrównuje rolę Mojżesza, Aarona i Miriam w wyzwoleniu narodu z niewoli egipskiej. Micheasz, jego zdaniem, dowartościowuje rolę Miriam, ponieważ w środowisku patriarchów żadna niewiasta nie była nigdy wcześniej nazwana prorokinią ${ }^{15}$. Tak jak Miriam odegrała istotną rolę w dziele Mojżesza, polegającym na wyzwoleniu Izraela, tak Maryja, według E. Zolli, odegrała istotną rolę w dziele odkupienia ludzkości dokonanym przez Chrystusa. Jeśli zatem Mojżesz był typem Chrystusa, to Miriam była typem Maryi ${ }^{16}$. Jeśli Miriam postrzegana jest jako uprzywilejowana przez Boga prorokini, to Maryja, nazwana błogosławioną między niewiastami, przywoływana jest w wierze Kościoła jako Królowa proroków. Według egzegezy alegorycznej drewno, z którego wykonany był koszyk ratujący życie Mojżeszowi, jest symbolem drewna, z którego wykonano krzyż dla Chrystusa. Sam koszyk natomiast postrzegany jest jako symbol grobu Chrystusa lub synagogi. Faraon nakazujący mordować nowo narodzonych chłopców izraelskich (por. Wj 1,22) symbolizuje Heroda, wydającego nakaz mordowania niemowląt narodzonych w Betlejem (por. Mt 2, 1-8. 12-23). Następnie Maryja i Józef zgubili dwunastoletniego Jezusa w Jerozolimie. Zgubili Go jako Syna (por. Łk 2, 48), a odnaleźli jako Boga (por. Łk 2, 49).

\section{Debora}

Żona Lappidota, prorokini sprawująca sądy nad Izraelem. Jabin, król Chasoru, przez dwadzieścia lat prowadził zwycięskie walki z Izraelem. Debora skłoniła dowódcę wojska, którym był Barak, do podjęcia ostatecznej walki z wojskiem Jabina. Kiedy zostało ono rozbite przez Izraelitów, Jael, żona Chebera Kenity, ukryła w swoim namiocie uciekającego z pola bitwy Siserę, dowódcę Jabina, a następnie go zabiła (por. Sdz 4, 17-22), przyczyniając się w ten sposób do wyzwolenia Izraela.

Uważana jest za symbol Maryi, ponieważ współpracowała z Barakiem, przyczyniając się wydatnie do pokonania Sisery i wyzwolenia ludu Izraela. Maryja współpracowała w dziele zbawczym Chrystusa (,Socia Christi”), przyczyniając

\footnotetext{
${ }^{15}$ Por. tamże, s. 47-48.

${ }^{16}$ Por. D. Ruotolo, Maria, chi mai sei tu?, Napoli 1975, s. 82.
} 
się do odkupienia rodzaju ludzkiego ${ }^{17}$. Po zwycięstwie nad Siserą Debora i Barak wyśpiewali dziękczynny hymn na cześć Boga, co zapowiada podobny hymn wypowiedziany przez Maryję w domu Zachariasza i Elżbiety (por. Łk 1, 46-55).

\section{Rut}

Moabitka i główna bohaterka Księgi Rut. W Ewangelii Mateusza przedstawiona jest jako prababka króla Dawida (por. Mt 1, 5-6). Z powodu głodu, jaki panował w okolicach Betlejem, Elimelek wraz z żoną Noemi i dwoma synami wyjechali do Moabu. Tam właśnie jeden z synów Elimeleka poślubił Rut. Po śmierci Elimeleka i obu synów Rut wraz z teściową Noemi powróciła do Betlejem. Na zasadzie prawa lewiratu (por. Kpł 25, 25-28; Rt 2, 20) została żoną Booza, który był krewnym męża Noemi. Została matką Obeda, którego synem z kolei był Jesse, ojciec Dawida.

Jest typem Maryi nie tylko ze względu na przynależność do rodu Dawida. Rut uważała się za pokorną służebnicę Booza, który wybrał ja na swą żonę. Maryja określa się mianem Służebnicy Pana, który uczynił z Niej Oblubienicę Ducha Świętego. Rut zbierała kłosy, jakie na polu Booza pozostawiali pracownicy, co dawało jej i teściowej nadzieję na przeżycie. Maryja zbiera wszystkich okaleczonych przez grzech i wskazuje im Chrystusa, który daje nie tylko nadzieję, ale i pewność życia wiecznego ${ }^{18}$. Mimo że nie była Żydówką, spełniała funkcję macierzyńską kobiet izraelskich: „Niech Pan uczyni kobietę, która wejdzie do twego domu, podobną do Racheli i Lei, które to dwie niewiasty zbudowały dom Izraela" (Rt 4, 11). Podobnie jak w przypadku Maryi, funkcja czy powołanie Rut nie było sprawą prywatną, ale było ukierunkowane na służbę innym ${ }^{19}$.

\section{Rispa}

Była nałożnicą Saula, syna Kisza z plemienia Beniamina, który został pierwszym królem wszystkich plemion izraelskich. Przyczyniła się do ostrego konfliktu między Iszbaalem, synem Saula i wielkim przeciwnikiem Dawida, a Abnerem, żołnierzem armii Saula i jego kuzynem a zarazem pretendentem do tronu po śmierci Saula (por. $2 \mathrm{Sm} \mathrm{3,8).} \mathrm{Iszbaal} \mathrm{oskarżył} \mathrm{Abnera} \mathrm{o} \mathrm{zamiar} \mathrm{poślubienia} \mathrm{Rispy,} \mathrm{nałożnicy}$ Saula. Efektem konfliktu było ich pogodzenie się z Dawidem, a tym samym Rispa przyczyniła się do zakończenia tzw. wojny siedmioletniej, która wybuchła po śmierci króla Saula (por. 2 Sm 3, 7-10). Zanim jednak do tego doszło, w kraju nastał głód

\footnotetext{
${ }^{17}$ Por. P. Pietrafesa, La Madonna nella Rivelazione, Napoli 1970, s. 30-40.

${ }^{18}$ Por. C. Lepre, Il libro di Ruth, Napoli 1981, s. 39-41.

${ }^{19}$ Por. A. Schökel, Introdución al libro de Rut, [w:] Rut, Tobia, Giuditta, Ester, Madrid 1973, s. 18.
} 
spowodowany trzyletnią suszą, a Dawid musiał wydać Gibeonitom siedmiu mężów jako zadośćuczynienie za prześladowanie ich przez króla Saula. Wydał im więc Armoniego i Meribbaala, synów Rispy, razem z pięcioma synami Merab, córki Saula, którzy zostali straceni przez powieszenie (por. $2 \mathrm{Sm}$ 21, 9). Przez trwający kilka miesięcy okres suszy Rispa osłaniała ciała wszystkich straconych przed atakami ptaków.

Co łączy Rispę z Maryją? Przede wszystkim obie były świadkami śmierci swych synów. Ph. Lefebvre dostrzega ścisły związek między imieniem Rispy a trybunałem, gdzie Piłat przesłuchiwał Jezusa (por. J 19, 13). Imię Rispy oddane jest przez Septuagintę jako greckie słowo Lithostrotos (por. $2 \operatorname{Sm~21;~} 2 \mathrm{Krn} \mathrm{7,} \mathrm{3;} \mathrm{Est} \mathrm{1,} \mathrm{6).}$ To z kolei w języku hebrajskim thumaczone jest przez Gabbata. Autor dostrzega w tym terminie aluzję do miejscowości Gibea, w której urodził się Saul i w której stracono jego potomków ${ }^{20}$. Żądanie, by Dawid wydał Gibeonitom siedmiu potomków Saula, wyrażone zostało w słowach: ,niech wydadzą nam siedmiu mężczyzn z jego potomków. Powiesimy ich wobec Pana na wzgórzu Saula, który był wybrańcem Pańskim” (2 Sm 21, 6). Jezus zapowiadając swoją śmierć robi to w słowach: „«A $\mathrm{Ja}$, gdy zostanę nad ziemię wywyższony, przyciągnę wszystkich do siebie». To powiedział zaznaczając, jaką śmiercią miał umrzeć" (J 12, 32-33). W Gibea Rispa patrzy na śmierć i czuwa nad ciałami straconych synów. Na Golgocie Maryja jest świadkiem ukrzyżowania Jej Syna. W Gibea, na wzgórzu Saula, macierzyństwo Rispy poszerzone zostaje o pięciu synów córki Saula. Na wzgórzu Golgoty macierzyństwo Maryi nabiera wymiaru powszechnego, gdy z woli Jej Syna zostaje duchową Matką wierzących w Niego. Po tragedii na wzgórzu Saula w kraju kończy się okres suszy, pada deszcz i wszystko powraca do nowego życia. Po dramacie na wzgórzu Golgoty ludzkie grzechy zostają odkupione, rozpoczyna się nowe życie w perspektywie zmartwychwstania ${ }^{21}$.

\section{Estera}

Księga Estery opisuje wyzwolenie Ludu Bożego dzięki pośrednictwu niewiasty. Księga ta stanowiła ulubioną lekturę liturgiczną Izraelitów, zwłaszcza podczas święta Purim. Powstała prawdopodobnie w połowie drugiego wieku przed Chrystusem. Jej bohaterka była córką Abichaila (por. Est 2, 15; 9, 29). W wieku młodzieńczym została wywieziona do Persji, gdzie jej krewny Mardocheusz pełnił wysoką funkcję na dworze króla Aswerusa. Po oddaleniu królowej Waszti jej miejsce zajęła Estera (por. Est 2, 8-18). Ponieważ Mardocheusz nie oddawał należnej czci Hamanowi,

${ }^{20}$ Por. Ph. Lefebvre, Rispah, la dame du Lithostrotos (2 Sam 21; J 19), ,Revue Biblique” 109 (2002), s. 235.

${ }^{21}$ Por. A. Serra, La donna dell'Alleanza, dz. cyt., s. 68-69. 
którego Aswerus uczynił pierwszym po sobie w królestwie, Haman postanowił zagładę Mardocheusza i wszystkich Żydów, nie wiedząc, że Żydówką jest również Estera. Na prośbę Mardocheusza Estera wstawiła się u króla za całym narodem, co doprowadziło do wycofania dekretu nakazującego zagładę Żydów i śmierci Hamana. Jego stanowisko objął Mardocheusz (por. Est 4, 1-9.19). W przeciwieństwie do Judyty, która przyczyniła się do wyzwolenia Izraela, zabijając dowódcę wojsk nieprzyjacielskich, Estera wykorzystała swoją urodę, posługując się jedynie pośrednictwem czy wstawiennictwem u króla.

$\mathrm{Z}$ tego też powodu teologia katolicka postrzega w Esterze typ Maryi. Chodzi zwłaszcza o doktrynę z zakresu pośrednictwa na rzecz nowego Ludu Bożego, czyli Kościoła. Estera pośredniczyła w przekazaniu królowi prośby Mardocheusza i Żydów. Decyzja jednak należała do króla. Maryja pośredniczy między ludźmi a Bogiem, do którego Kościół kieruje swoje prośby. Dawcą łaski nie jest Maryja, ale Bóg22. Ponadto obie niewiasty, Estera i Maryja, odznaczały się równie silną i wytrwałą wiarą, o czym świadczyć mogą modlitwa tej pierwszej:

Panie mój, Królu nasz, Ty jesteś jedyny, wspomóż mnie samotną, nie mającą prócz Ciebie [żadnego] wspomożyciela, bo niebezpieczeństwo jest niejako w ręce mojej. [...] O Boże potężny nad wszystkimi, wysłuchaj głosu pozbawionych nadziei i wyratuj nas z ręki niegodziwych, mnie zaś uwolnij od mego lęku (Est 4, 17),

i modlitwa dziękczynna Maryi wypowiedziana w domu Zachariasza i Elżbiety (por. Łk 1, 46-55).

\section{Matka Machabeuszów}

Machabeusze byli rodem arcykapłańskim i królewskim, który przez wiele pokoleń sprawował władzę w Palestynie i Jerozolimie. Arystobulos II był ostatnim królem tej dynastii. W 63 roku przed Chrystusem Pompejusz zniszczył królestwo machabejskie, a Palestynę podporządkował cesarstwu rzymskiemu. Druga Księga Machabejska opisuje męczeńską śmierć siedmiu bezimiennych braci machabejskich (nazwanych tak raczej ze względu na epokę) oraz obecność przy tej śmierci ich matki (por. 2 Mch 7,1-41). Biblia podaje, że towarzyszyła ona w ciągu jednego dnia śmierci swych siedmiu synów i każdego zachęcała do wierności Bogu, mówiąc do nich:

Nie wiem, w jaki sposób znaleźliście się w moim łonie, nie ja wam dałam tchnienie i życie, a członki każdego z was nie ja ułożyłam. Stwórca świata bowiem, który ukształtował człowieka

${ }^{22}$ Por. C. I. González, Mariologia, dz. cyt., s. 39. 
i wynalazł początek wszechrzeczy, w swojej litości ponownie odda wam tchnienie i życie, dlatego że wy gardzicie sobą teraz dla Jego praw (2 Mch 7, 22-23).

Apokryficzna IV Księga Machabejska nazywa ją „matką narodu”, „ostoją pobożności”, „świętą i bogobojną matką”. Kierowana szlachetną miłością do Boga, zachęcała synów do wytrwania w wierze ojców nawet za cenę śmierci, bo tylko w ten sposób dostąpią zmartwychwstania.

Świadkiem egzekucji na Synu była również Maryja. Kanoniczna Księga Machabejska podaje, że „Przede wszystkim zaś godna podziwu i trwałej pamięci była matka. Przyglądała się ona w ciągu jednego dnia śmierci siedmiu synów i zniosła to mężnie. Nadzieję bowiem pokładała w Panu" (2 Mch 7, 20). W godzinie krzyża Matka Jezusa również doświadcza radykalnej próby wiary i spełnia swą macierzyńską misję, ponieważ wierzy, że Bóg „strąca władców z tronu, a wywyższa pokornych” $\left(Ł k\right.$ 1, 52) tak, jak czynił to w przeszłości ${ }^{23}$.

\section{Judyta}

Była córką Merariego z pokolenia Symeona i wdową po Manassesie z Betulii, $z$ tego samego pokolenia. To dzięki niej Izraelici odnieśli zwycięstwo nad przeważającymi siłami wojsk asyryjskich. Król Asyrii Nabuchodonozor i dowódca jego wojska Holofernes wystąpili przeciw Izraelowi, który nie chciał uznać dominacji asyryjskiej. Oblężona przez Holofernesa Betulia mogła jedynie albo się poddać, albo zginąć śmiercią głodową. Judyta udała się do obozu Holofernesa, któremu przedstawiła się jako uciekinierka, a następnie po trzech dniach w jego własnym namiocie odcięła mu głowę. Asyryjczycy po zorientowaniu się, że ich wódz zginął $\mathrm{z}$ ręki kobiety, odstąpili od wojny. Wulgata podaje nawet, że za czyn ten ustanowiono ku jej czci specjalne święto (por. Jdt 16, 25).

Opis tego wydarzenia nie wydaje się autentyczny. Przede wszystkim Nabuchodonozor nie był nigdy królem Asyrii. Był królem Babilonii w latach 604-541 przed Chrystusem Egzegeci uważają Księgę Judyty bądź to za utwór alegoryczny, bądź też nawet za apokryf. Zważywszy, że najprawdopodobniej powstała ona w okresie machabejskim (około 175 przed narodzeniem Chrystusa), kiedy potrzeba było konkretnych przykładów zachęty do trwania w wierze ojców, autor wykorzystał bliżej nieokreśloną wojnę, w której Izrael odniósł zwycięstwo dzięki bohaterstwu kobiety. Nie brak też egzegetów twierdzących, że Nabuchodonozor i Holofernes symbolizują Antiocha IV, a Judyta wspólnotę żydowską, która za wierność wyznawanej religii skazana została na zniszczenie ${ }^{24}$. Natomiast istota przesłania księgi

${ }^{23}$ Por. D. Flusser, Il Cristianesimo. Una religione ebraica, Milano 1992, s. $26-27$.

${ }^{24}$ Por. A. Serra, La Donna dell'Alleanza, dz. cyt., s. 76-77. 
i dzieła Judyty sprowadza się do przekonania, że w każdym ucisku i zniewoleniu mocą i siłą Izraela pozostaje jego wierność Panu ${ }^{25}$.

Po bohaterskim czynie Judyty król Ozjasz wypowiedział słowa błogosławieństwa:

Błogosławiona jesteś, córko, przez Boga Najwyższego, spomiędzy wszystkich niewiast na ziemi, i niech będzie błogosławiony Pan Bóg, Stwórca nieba i ziemi, który cię prowadził, abyś odcięła głowę wodza naszych nieprzyjaciół. Twoja ufność nie zatrze się aż na wieki w sercach ludzkich wspominających moc Boga (Jdt 13, 18-19).

Podobne słowa znajdujemy w Ewangelii Łukasza, a kieruje je do Maryi Matka Jana Chrzciciela: „Błogosławiona jesteś między niewiastami i błogosławiony jest owoc Twojego łona. A skądże mi to, że Matka mojego Pana przychodzi do mnie" (Łk 1, 42-43). Słowa błogosławieństwa obu niewiast są niemal identyczne: „Błogosławiona jesteś, córko, przez Boga Najwyższego, spomiędzy wszystkich niewiast na ziemi, i niech będzie błogosławiony Pan Bóg, Stwórca nieba i ziemi” $(J d t 13,18)$ oraz „Błogosławiona jesteś między niewiastami i błogosławiony jest owoc Twojego łona" (Łk 1, 42).

Skoro Judyta i Maryja mają być błogosławione wśród wszystkich niewiast na ziemi, to błogosławieństwo owo dotyczy nie tylko narodu izraelskiego, ale także innych. W liturgii do Maryi odnoszone są ponadto słowa, jakie do Judyty skierował arcykapłan Jakim: „Tyś wywyższeniem Jeruzalem, tyś chlubą wielką Izraela, tyś wielką dumą naszego narodu" (Jdt 15, 9).

\section{Summary}

\section{Mothers of Israel as the type of Mother of Church}

The Bible very little attention pays to the Mother of God. Apart from the Gospels of Childhood there are only two known mentions from the public period of Jesus' activity. These are the wedding in Cana and the description of Christ' crucifixion. The beloved disciple does not even mention Mary's name. He replaces it with such words as: Mother of Lord, Jesus' Mother, His Mother. The Old Testament does not refer to Mary directly. There are many texts though that according to the symbolic sense and prophets' predictions refer to Mary's motherhood towards expected Messiah and Her participation in His redemptive act.

It refers especially to the Old Testament "Mothers" of Israel who played a crucial role in history of this nation both through its religious formation during the periods of unfaithfulness to Covenant and through the participation in the liberation from slavery and alien invasion, when the history of Israel at the same time the history

${ }^{25}$ Por. A. Schökel, Introdución al libro de Rut, dz. cyt., s. 20. 
of redemption and became the theology of Israeli Nation. Through a place and a role of these Mothers in the liberation of Israel the Christian exegesis, following the patristic tradition, defines the place and the role of Mary in the redemption of man fulfilled by Christ.

\section{Keywords}

Mary, Mother, salvation history, Israel, covenant, liberation, redemption, typical sense 
